\title{
Editorial \\ Integrating Ecology and Society to Navigate Turbulence
}

\author{
$\underline{\text { Lance Gunderson }}^{1}$, Carl Folke $^{2}$, and $\underline{\text { Marco Janssen }}^{3}$
}

Since the last issue of Ecology and Society, one major environmental event has dominated the news and reminded us of the increasing complexity and turbulence of environmental change in our times. That event was the devastating tsunami in the Indian Ocean, which was the worst natural disaster, in terms of human casualties, in a generation. The tsunami has had varying effects on the ecology and society of the region and will change the future of both in unknown ways. From coastal marine systems such as lagoons and reefs to coastal forests to inland marshes and riparian systems, primary successional processes are under way. In the social domain, new configurations will emerge because the resilience of the prior system was exceeded. That reorganization is based in large part on the influx of many forms of human, fiscal, and social capital. Nevertheless, other environmental issues persist and grow at other scales.

Examining these issues through a lens that integrates ecology and society is a way of understanding the complexity of these issues. Capturing, communicating, and expanding that understanding are the ongoing goals of this journal. As you can see from the number and nature of the submissions, understanding and managing these forms of turbulence are not as simple as "turning on the seatbelt sign," which is the common form of turbulence management on aircraft. The contributions to this issue indicate how humans are adding to the turbulence of change, as human actions continue to generate a loss of resilience and increased susceptibility to the loss of ecosystem goods and services.

This issue suggests the truly global extent of the community of the scholars who contribute to Ecology and Society. It is the largest issue in terms of contribution that we have produced so far. There are 42 contributions, including seven for the special features in progress, two book reviews, and four responses. Biodiversity conservation is a common, worldwide theme and is addressed in submissions on subjects such as the implications of current ecological thinking for biodiversity conservation (Wallington et al. 2005), the role of informal protected areas in maintaining biodiversity in India (Bhagwat et al. 2005), areas for field conservation of forages in Latin America (Peters et al. 2005), the impact on adjacent parks of logging in equatorial Africa (Baidya Roy et al. 2005), and the biodiversity impacts associated with coffee production in four villages in Mexico (Potvin et al. 2005).

Another theme is how humans are modifying the social and ecological dimensions of coupled systems. Articles on this theme examine the interactions among fire, livelihoods, and environmental change in East Kalimantan (Chokkalingam et al. 2005) and the role of technology in understanding land-use change in Vietnam (Castella et al. 2005).

Integrating ecology and society in forest management is another thematic focus in this issue. This theme is expressed in studies of ecosystem services of tropical dry forests in Mexico (Maass et al. 2005), tropical forest restoration in Galapagos National Park (Wilkinson et al. 2005), remote sensing and ethnobotanical assessment of Mexican mangrove forests (Hernández Cornejo et al. 2005), forest management in Nepal (Nagendra et al. 2005), and collaborative monitoring of timber harvests in the Brazilian Amazon (Pokorny et al. 2005).

A fourth theme is the melding of ecology and society in human-dominated and transformed landscapes. This theme encompasses subjects such as socioeconomic and cultural dimensions of urban biodiversity (Kinzig et al. 2005), landscape patterns of $40 \mathrm{yr}$ of exurban growth in the United States (Theobald 2005), management of habituated urban 
wildlife (Kloppers et al. 2005), risk management of genetically engineered crops in nonindustrialized agriculture (Cleveland and Soleri 2005), mechanisms affecting population density in fragmented habitat (Tischendorf et al. 2005), limitations in least-cost modeling of the distances between habitat patches to assess connectivity (Rothley 2005), humaninduced regime shifts and loss of ecosystem services in Sweden (Troell et al. 2005), the role of climate variability in tularemia dynamics in humans and mammals (Palo et al. 2005), the history of the lobster and conch fisheries in Belize (Huitric 2005), the incorporation of scientific knowledge into land-use policy on a local scale (Francis et al. 2005), the contribution of local knowledge about migratory birds to management (Gilchrist et al. 2005), and socioeconomic factors shaping customary marine tenure in the Indo-Pacific (Cinner 2005).

Finally, this issue contains contributions addressing conceptual the underpinnings and perspectives of ecology and society, including a comprehensive synthesis of the evolution of the ecosystem approach (Waltner-Toews and Kay 2005), ideas of change and identity in complex systems (Cumming and Collier 2005), a framework for global collaboration in social-ecological research (Schweik et al. 2005), myths underlying restoration ecology (Hilderbrand et al. 2005), and a perspective on the evolution of e-dialogs in interdisciplinary research in Canada (Dale 2005).

\section{SPECIAL FEATURES}

Two contributions have been published in the new special feature on Riverine landscapes edited by Christer Nilsson. One is a historical perspective on the management of river basins in the United States (Reuss 2005); the other addresses the challenge of accommodating variability and designing trajectories in restoration (Hughes et al. 2005). There are also three new papers in the special feature on Urban sprawl. Two of those describe the effects of urban sprawl on biodiversity and species behavior (Christie and Hochuli 2005, Forys and Allen 2005), and the third analyzes trade-offs in urban change among development, socioeconomic, and ecological issues in the Pittsburgh area (Haller 2005). Finally, Erin Bohensky and Tim Lynam (2005) provide insights from water management in Southern Africa in their contribution to the special feature on the subglobal Millennium Ecosystem Assessment edited by Christo Fabricius.

\section{BOOK REVIEWS AND RESPONSES}

We invite the readers to examine the growing list of book reviews and comments to previous articles in this issue. This issue also marks the end of the annual Ralf Yorque Memorial Competition, as described by the coordinator of the program, Marco Janssen.

\section{THE RALF YORQUE MEMORIAL COMPETITION}

The Ralf Yorque Memorial Competition 2004 has been closed. Nineteen manuscripts were submitted, and seven of those passed the peer-review process. The accepted papers appear in this issue of Ecology and Society. This competition is intended to help foster discovery, innovation, and originality by seeking manuscripts that effectively and imaginatively practice research across disciplines and use the World Wide Web to communicate complex transdisciplinary ideas. A committee of three judges, C. S. Holling, M. A. Janssen, and B. H. Walker, deliberated and voted on these seven articles to determine the winner of the prize.

"Emergence Unites Ecology and Society," submitted by Ronald Trosper (2005), was chosen as the winner of the Ralf Yorque Memorial Competition 2004. Trosper argues that emergence is a possible unifying concept that can be used to study social-ecological systems. Emergence has been a topic of interest in both the social and the natural sciences, and Trosper brings the different streams of emergence research together. He uses the example of forest fires to illustrate this idea and points to the relevance of the emergence concept to issues at the transitions across scales and across cultural, economic, and ecological dimensions. He develops a truly integrative framework by incorporating slow variables such as cultural, material, and social structures. This perspective provides the material for novel hypotheses for future transdisciplinary research in the area of ecology and society. The committee decided to grant Trosper the prize of 5000 Euro provided by the Foundation for Scientific Symbiosis.

One reason for the small number of entries in this year's competition is the fact that, despite some discussion of the use of new media for research and the inclusion of movies and colorful figures, few submissions described truly innovative uses of the 
World Wide Web. As a result, we have decided to change the focus of future Ralf Yorque competitions, which will deal exclusively with creative transdisciplinary research in the field of ecology and society. New manuscripts submitted in the first six months of the year will be considered for the Ralf Yorque Memorial Competition if the author chooses this option at the time of submission and provides a clear description of the innovative features of the topic covered in the manuscript. As usual, each manuscript has to pass the peer-review process to become a candidate for the Ralf Yorque Memorial Prize. A committee of scholars will judge the papers and select the winner. We hope that this redirection of the annual competition will continue to stimulate ideas on creative transdisciplinary research.

Finally, the editors of Ecology and Society are very pleased to provide our readers with such a rich set of innovative and exciting contributions on integrative science for resilience and sustainability.

Responses to this article can be read online at:

http://www.ecologyandsociety.org/volXX/issYY/artZZ/responses/

\section{LITERATURE CITED}

Baidya Roy, S., P. D. Walsh, and J. W. Lichstein. 2005. Can logging in equatorial Africa affect adjacent parks? Ecology and Society 10(1): 6 . [online] URL:

/http://www.ecologyandsociety.org/vol10/iss1/art6/

Bhagwat, S., C. Kushalappa, P. Williams, and N. Brown. 2005. The role of informal protected areas in maintaining biodiversity in the Western Ghats of India. Ecology and Society 10(1): 8. [online] URL: http://www.ecologyandsociety.org/vol10/iss1/art8/

Bohensky, E., and T. Lynam. 2005. Evaluating responses in complex adaptive systems: insights on water management from the Southern African Millennium Ecosystem Assessment (SAfMA). Ecology and Society 10(1): 11. [online] URL: http://www.ecologyandsociety.org/vol10/iss1/art11/

Castella, J. C., Tran Ngoc Trung, and S. Boissau. 2005. Participatory simulation of land-use changes in the northern mountains of Vietnam: the combined use of an agent-based model, a role-playing game, and a geographic information system. Ecology and Society 10(1): 27. [online] URL:

http://www.ecologyandsociety.org/vol10/iss1/art27/

Chokkalingam, U., I. Kurniawan, and Y. Ruchiat. 2005. Fire, livelihoods, and environmental change in the Middle Mahakam peatlands, East Kalimantan. Ecology and Society 10(1): 26. [online] URL:

http://www.ecologyandsociety.org/vol10/iss1/art26/

Christie, F. J., and D. F. Hochuli. 2005. Elevated levels of herbivory in urban landscapes: are declines in tree health more than an edge effect? Ecology and Society 10(1): 10. [online] URL:

http://www.ecologyandsociety.org/vol10/iss1/art10/

Cinner, J. 2005. Socioeconomic factors influencing customary marine tenure in the Indo-Pacific. Ecology and Society 10(1): 36. [online] URL:

http://www.ecologyandsociety.org/vol10/iss1/art36/

Cleveland, D. A., and D. Soleri. 2005. Rethinking the risk management process for genetically engineered crop varieties in small-scale, traditionally based agriculture. Ecology and Society 10(1): 9. [online] URL:

http://www.ecologyandsociety.org/vol10/iss1/art9/

Cumming, G. S., and J. Collier. 2005. Change and identity in complex systems. Ecology and Society 10(1): 29. [online] URL:

http://www.ecologyandsociety.org/vol10/iss1/art29/

Dale, A. 2005. A perspective on the evolution of edialogue concerning interdisciplinary research on sustainable development in Canada. Ecology and Society 10(1): 37. [online] URL:

http://www.ecologyandsociety.org/vol10/iss1/art37/

Forys, E., and C. R. Allen. 2005. The impacts of sprawl on biodiversity: the ant fauna of the lower Florida Keys. Ecology and Society 10(1): 25. [online] URL:

http://www.ecologyandsociety.org/vol10/iss1/art25/ 
Francis, T., K. Whittaker, V. Shandas, A. V. Mills, and J. K. Graybill. 2005. Incorporating science into the environmental policy process: a case study from Washington State. Ecology and Society 10(1): 35. [online] URL:

http://www.ecologyandsociety.org/vol10/iss1/art35/

Gilchrist, G., M. Mallory and F. Merkel. 2005. Can local ecological knowledge contribute to wildlife management? Case studies of migratory birds. Ecology and Society 10(1): 20. [online] URL: http://www.ecologyandsociety.org/vol10/iss 1/art20/

Haller, W. 2005. Industrial restructuring and urban change in the Pittsburgh region: developmental, ecological, and socioeconomic trade-offs. Ecology and Society 10(1): 13. [online] URL:

http://www.ecologyandsociety.org/vol10/iss1/art13/

Hernández Cornejo, R., N. Koedam, A. Ruiz Luna, M. Troell, and F. Dahdouh-Guebas. 2005. Remote sensing and ethnobotanical assessment of the mangrove forest changes in the Navachiste-San Ignacio-Macapule lagoon complex, Sinaloa, Mexico. Ecology and Society 10(1): 16. [online] URL:

http://www.ecologyandsociety.org/vol10/iss 1/art16/

Hilderbrand, R. H., A. C. Watts, and A. M. Randle. 2005. The myths of restoration ecology. Ecology and Society 10(1): 19. [online] URL:

http://www.ecologyandsociety.org/vol10/iss1/art19/

Hughes, F. M., R., A. Colston, and J. Owen Mountford. 2005. Restoring riparian ecosystems: the challenge of accommodating variability and designing restoration trajectories. Ecology and Society 10(1): 12. [online] URL:

http://www.ecologyandsociety.org/vol10/iss1/art12/

Huitric, M. 2005. Lobster and conch fisheries of Belize: a history of sequential exploitation. Ecology and Society 10(1): 21. [online] URL:

http://www.ecologyandsociety.org/vol10/iss1/art21/
Kinzig, A. P., P. Warren, C. Martin, D. Hope, and M. Katti. 2005. The effects of human socioeconomic status and cultural characteristics on urban patterns of biodiversity. Ecology and Society 10(1): 23. [online] URL:

http://www.ecologyandsociety.org/vol10/iss1/art23/

Kloppers, E. L., C. C. St. Clair, and T. E. Hurd. 2005. Predator-resembling aversive conditioning for managing habituated wildlife. Ecology and Society 10(1): 31. [online] URL:

http://www.ecologyandsociety.org/vol10/iss1/art31/

Maass, J., P. Balvanera, A. Castillo, G. C. Daily, H. A. Mooney, P. Ehrlich, M. Quesada, A. Miranda, V. J. Jaramillo, F. García-Oliva, A. Martínez-Yrizar, H. Cotler, J. López-Blanco, A. Pérez-Jiménez, A. Búrquez, C. Tinoco, G. Ceballos, L. Barraza, R. Ayala, and J. Sarukhán. 2005. Ecosystem services of tropical dry forests: insights from long-term ecological and social research on the Pacific Coast of Mexico. Ecology and Society 10(1): 17. [online] URL:

http://www.ecologyandsociety.org/vol10/iss1/art17/

Nagendra, H., M. Karmacharya, and B. Karna. 2005. Evaluating forest management in Nepal: views across space and time. Ecology and Society 10(1): 24. [online] URL:

http://www.ecologyandsociety.org/vol10/iss1/art24/

Palo, T. R., C. Ahlm, and A. Tärnvik. 2005. Climate variability reveals complex events for tularemia dynamics in man and mammals. Ecology and Society 10(1): 22. [online] URL:

http://www.ecologyandsociety.org/vol10/iss1/art22/

Pokorny, B., and M. Steinbrenner. 2005. Collaborative monitoring of production and costs of timber harvest operations in the Brazilian Amazon. Ecology and Society 10(1): 3. [online] URL:

http://www.ecologyandsociety.org/vol10/iss1/art3/

Potvin, C., C. T. Owen, S. Melzi, and P. Beaucage. 2005. Biodiversity and modernization in four coffee-producing villages of Mexico. Ecology and Society 10(1): 18. [online] URL:

http://www.ecologyandsociety.org/vol10/iss1/art18/ 
Reuss, M. 2004. Ecology, planning, and river management in the United States: some historical reflections. Ecology and Society 10(1): 34. [online] URL:

http://www.ecologyandsociety.org/vol10/iss1/art34/

Rothley, K. 2005. Finding and filling the "cracks" in resistance surfaces for least-cost modeling. Ecology and Society 10(1): 4. [online] URL:

http://www.ecologyandsociety.org/vol10/iss1/art4/

Schweik, C., T. Evans, and J. Grove. 2005. Open source and open content: a framework for global collaboration in social-ecological research. Ecology and Society 10(1): 33. [online] URL:

http://www.ecologyandsociety.org/vol10/iss 1/art33/

Theobald, D. 2005. Landscape patterns of exurban growth in the United States from 1980 to 2020. Ecology and Society 10(1): 32. [online] URL:

http://www.ecologyandsociety.org/vol10/iss1/art32/

Tischendorf, L., A. Grez, T. Zaviezo, and L. Fahrig. 2005. Mechanisms affecting population density in fragmented habitat. Ecology and Society 10(1): 7. [online] URL:

http://www.ecologyandsociety.org/vol10/iss1/art7/

Troell, M., L. Pihl, P. Rönnbäck, H. Wennhage, T. Söderqvist, and N. Kautsky. 2005. Regime shifts and ecosystem service generation in Swedish coastal soft bottom habitats: when resilience is undesirable. Ecology and Society 10(1): 30. [online] URL:

http://www.ecologyandsociety.org/vol10/iss1/art30/

Trosper, R. L. 2005. Emergence unites ecology and society. Ecology and Society 10(1): 14. [online] URL:

http://www.ecologyandsociety.org/vol10/iss1/art14/

Wallington, T. J., R. J. Hobbs, and S. A. Moore. 2005. Implications of current ecological thinking for biodiversity conservation: a review of the salient issues. Ecology and Society 10(1): 15. [online]
URL:

http://www.ecologyandsociety.org/vol10/iss1/art15/

Waltner-Toews, D., and J. Kay. 2004. The evolution of an ecosystem approach: the diamond schematic and an adaptive methodology for ecosystem sustainability and health. Ecology and Society 10(1): 38. [online] URL:

http://www.ecologyandsociety.org/vol10/iss 1/art38/

Wilkinson, S. R., M. A. Naeth, and F. K. A. Schmiegelow. 2005. Tropical forest restoration within Galapagos National Park: application of a state-transition model. Ecology and Society 10(1): 28. [online] URL:

http://www.ecologyandsociety.org/vol10/iss1/art28/ 